\title{
PENGUJIAN ARBITRAGE PRICING THEORY (APT) SEBAGAI PREDICTOR PENGEMBALIAN SAHAM YANG DIHARAPKAN ( STUDI KASUS PADA INDUSTRI PERBANKAN YANG TERDAFTAR DI BURSA EFEK INDONESIA)
}

\author{
Oleh : \\ Fanda Daisy Prully Rundengan \\ Tommy Parengkuan \\ Ivonne Saerang \\ Magister Manajemen, Fakultas Ekonomi dan Bisnis \\ Universitas Sam Ratulangi Manado \\ email : daisyfandarundengan@gmail.com
}

\begin{abstract}
ABSTRAK
Dampak krisis ekonomi yang terjadi menyebabkan para investor mengalami kesulitan dalam menganalisis dan memprediksi pendapatan saham perusahaan. Tidak terkecuali saham-saham industri perbankan yang terdaftar pada bursa efek Indonesia (BEI). Dalam memprediksi pendapatan saham yang diharapkan, ada dua model yang sering digunakan para investor, yaitu capital asset pricing model (CAPM) dan arbitrase pricing theory (APT). APT pada dasarnya menggunakan pemikiran yang menyatakan bahwa dua kesempatan investasi yang mempunyai karakteristik yang identik sama tidaklah bisa dijual dengan harga yang berbeda. Konsep yang dipergunakan adalah hukum satu harga (the law of one price). Analisa yang digunakan dalam penelitian adalah analisis uji beda dua rata-rata. Dimana membandingkan sepuluh industri perbankan yang terdaftar diBursa Erfek Indonesia (BEI). Setelah melakukan uji hipotesa menggunakan SPSS maka di peroleh output berupa hasil pengujian beda dua rata-rata dependent samples, bahwa $t_{\text {hitung }}$ untuk pengujian APT dengan membandingkan actual return (Ri) dan expected return (ERi) saham dengan equal variance asumet. Hasil penelitian menunjukan bahwa expected return tidak berbeda signifikan dengan actual return ini berarti hipotesis menyatakan diduga expected return hasil prediksi model Arbitrage Pricing Theory sama dengan actual return pada industri perbankan yang go public di Bursa Efek Indonesia ditolak, oleh karena expected return tidak berbeda signifikan dengan actual return maka model Arbitrage Pricing Theory Akurat. Hasil penelitian yang dilakukan oleh penulis, menyatakan bahwa pengujian APT (Arbitrase Pricing Theory) dengan membandingkan Actual return (Ri) dengan Expected return (ERi) untuk mengukur tingkat pengembalian saham adalah tidak terdapat perbedaan. Ini berarti bahwa APT tidak memberikan dampak tingkat pengembalian saham pada industri perbankan yang go public di bursa efek Indonesia.
\end{abstract}

Kata Kunci: Arbitrage Pricing Theory, Expected return, Actual return.

\begin{abstract}
The impact of the economic crisis caused investors have difficulty in analyzing and predicting stock returns of the company. No exception to the banking industry shares are listed on the Indonesia Stock Exchange (BEI). In predicting stock returns are expected, there are two models that are often used by investors, the capital asset pricing model (CAPM) and the arbitrage pricing theory (APT). APT basically use reasoning stating that two investment opportunities that have the same characteristics identical bias not sold with different prices. The concept used is hokum one price (the law of one price). Analysis used in the study is the analysis of two different test average. Where comparing ten banking industry Stock Exchange Securities registered Indonesian (IDX). After conducting a hypothesis test using the SPSS output in the form of test results obtained bedadua average dependent samples, bahwathitung for APT testing by comparing the actual return (Ri) and expected return (ERI) stock with a variance equal to propabilitas assumet is $0.2900,1.620$. Therefore, P-value $0.290>0.05$, results showed that the expected return is not berbedas ignifikan with actual return (significant 0.290) This means that the hypothesis stated: "Allegedly expected return results Arbitrage Pricing Theory model predictions with actual return on the banking industry that went public in the Indonesia Stock Exchange rejected. Therefore, the expected return does not differ significantly from the actual return the Arbitrage Pricing Theory Accurate models. Results of research conducted by the author, states that testing APT (Arbitrage Pricing Theory) by comparing Actual return (Ri) with Expected return (ERI) to measure stock returns is no difference. This means that the APT does not affect stock returns padaindustri banks that went public on the stock exchanges of Indonesia.
\end{abstract}

Key Words: Arbitrage Pricing Theory, Expected return, Actual Return 


\section{Latar Belakang}

\section{PENDAHULUAN}

Dampak krisis ekonomi global sangat dirasakan oleh para pelaku pasar modal karena pasar modal merupakan salah satu penggerak perekonomian suatu negara. Ketidakstabilan ekonomi pada masa krisis membuat pelaku pasar modal terutama para investor mengalami kesulitan dalam menganalisis dan memprediksi pendapatan saham perusahaan yang berfluktuasi.

Dalam memprediksi pendapatan saham yang diharapkan dalam ilmu investasi terdapat dua model keseimbangan yang sering digunakan para investor, yaitu Capital Asset Pricing Model (CAPM) dan Arbitrase Pricing Theory (APT).Capital Assets Pricing Model (CAPM) menjelaskan tentang hubungan antara return dan beta yang diperkenalkan oleh Sharp (1964) dan lintner (1965) model untuk menentukan harga suatu assets pada kondisi equilibrium.

Kelemahan-kelemahan empiris yang terjadi pada model Capital Asset Pricing Model mendorong para ahli manajemen keuangan untuk mencari model alternatif yang menerangkan hubungan pendapatan dengan resiko saham. Pada tahun 1976 Ross merumuskan sebuah teori yang disebut dengan Arbitrase Pricing Theory (APT), yang merupakan sebuah model keseimbangan alternative lebih kompleks di banding Capital Asset Pricing Model dikatakan demikian karena Arbitrase Pricing Theory (APT) mengunakan sekian banyak variable pengukur risiko untuk melihat hubungan risiko dan return. Meskipun model ini tidak bisa secara keseluruhan memecahkan kekurangan yang terjadi pada model Capital Asset Pricing Model, tetapi model inilah yang pertama kali dikembangkan perbandingan keakuratan capital assets pricing model dengan Arbitrage Pricing Theory dalam memprediksi tingkat pendapatan saham industri manufaktur sebelum dan semasa krisis ekonomi (Premananto dan Madyan, 2002)

Dengan melihat latar belakang diatas penulis ingin meneliti lebih lanjut tentang Arbitrase Pricing Theory, apakah dapat mempengaruhi tingkat pengembalian saham atau tidak. Untuk itu peneliti mengambil judul dalam penelitian ini Pengujian Arbitrase Pricing Theory (APT) sebagai predictor pengembalian saham yang diharapkan.

Industri Perbankan yang di teliti dalam penelitian ini adalah 10 Perbankan dari 38 perbankan yang terdaftar di bursa efek Indonesia (BEI). Kesepuluh Perbankan tersebut adalah :

1. PT. Bank Mandiri (Persero), Tbk

2. PT. Bank Rakyat Indonesia, Tbk

3. PT. Bank Central Asia, Tbk

4. PT. Bank Negara Indonesia (Persero), Tbk

5. PT. Bank CIMB Niaga, Tbk

6. PT. Bank Danamon, Tbk

7. PT. Bank Permata, Tbk

8. PT. Bank Tabungan Pensiunan Negara, Tbk

9. PT. Bank OCBC NSIP, Tbk

10.PT. Bank Mega Tbk

Adapun indikator yang diukur adalah harga saham dari masing-masing perusahaan antara bulan januari sampai desember 2011 yang tercermin pada tabel dibawah ini : 
Tabel 1. Harga Saham

\begin{tabular}{|l|l|l|l|l|l|l|l|l|l|l|l|l|l|}
\hline $\begin{array}{l}\text { NAMA } \\
\text { PERUSAHAAN }\end{array}$ & JAN & FEB & MAR & APR & MEI & JUN & JUL & $\begin{array}{l}\text { AGS } \\
\text { T SEP }\end{array}$ & OKT & NOV & DES & Satuan \\
\hline $\begin{array}{l}\text { PT. Bank Mandiri } \\
\text { Tbk }\end{array}$ & 5950 & 5800 & 6800 & 7150 & 7200 & 7200 & 7850 & 6850 & 6300 & 750 & 6400 & 6750 & Rupiah \\
\hline $\begin{array}{l}\text { PT. Bank Rakyat } \\
\text { Indonesia, Tbk }\end{array}$ & 4850 & 4700 & 6450 & 6350 & 6500 & 6900 & 6550 & 5850 & 6750 & 6500 & 5850 & 6750 & Rupiah \\
\hline $\begin{array}{l}\text { PT. Bank Central } \\
\text { Asia, Tbk }\end{array}$ & 5650 & 6300 & 6950 & 7400 & 7100 & 7650 & 8300 & 8000 & 7700 & 8100 & 7900 & 8000 & Rupiah \\
\hline $\begin{array}{l}\text { PT. Bank Negara } \\
\text { Indonesia, Tbk }\end{array}$ & 3225 & 3550 & 3975 & 4050 & 3875 & 3875 & 4450 & 4125 & 3725 & 4025 & 3800 & 3800 & Rupiah \\
\hline $\begin{array}{l}\text { PT. Bank CIMB } \\
\text { Niaga, Tbk Bank }\end{array}$ & 1320 & 1260 & 1430 & 1400 & 1320 & 1300 & 1240 & 1210 & 1100 & 1100 & 1080 & 1080 & Rupiah \\
\hline $\begin{array}{l}\text { PT. } \\
\text { Danamon, Tbk }\end{array}$ & 5950 & 6400 & 6550 & 6200 & 6200 & 6000 & 5450 & 5200 & 4600 & 4975 & 4400 & 4100 & Rupiah \\
\hline $\begin{array}{l}\text { PT. Bank Permata, } \\
\text { Tbk }\end{array}$ & 1350 & 1670 & 1840 & 1750 & 1700 & 1620 & 1680 & 1570 & 1540 & 1470 & 1430 & 1360 & Rupiah \\
\hline $\begin{array}{l}\text { PT. } \\
\text { Tabungan Bank } \\
\begin{array}{l}\text { Pensiunan Negara, } \\
\text { Tbk }\end{array}\end{array}$ & 12800 & 11800 & 2500 & 2975 & 3125 & 3250 & 3800 & 3775 & 3325 & 3750 & 3400 & 3400 & Rupiah \\
\hline $\begin{array}{l}\text { PT. Bank OCBC } \\
\text { NISP, Tbk }\end{array}$ & 1360 & 1260 & 1430 & 1400 & 1320 & 1300 & 1240 & 1210 & 1100 & 1100 & 1080 & 1080 & Rupiah \\
\hline $\begin{array}{l}\text { PT. Bank Mega, } \\
\text { Tbk }\end{array}$ & 3150 & 3000 & 3100 & 3800 & 3550 & 3525 & 2700 & 3500 & 3500 & 3500 & 3500 & 3500 & Rupiah \\
\hline
\end{tabular}

Sumber : Indonesia Stock Exchange (IDX), Jurnal of Economic(gur huberman "a simple approace to arbitrase pricing theory, october 1982:183 - 191")

Sejak kelahirannya pada pertengahan tahun 1970-an, teori penentuan harga Arbitrage Pricing Theory telah memberikan kerangka kerja yang intuitif dan fleksibel bagi periset dan praktisi sehingga mereka mampu mengatasi isu manajemen investasi yang penting. Berlawanan dengan Capital Asset Pricing Model yang memerlukan asumsi-asumsi spesifik mengenai pilihan investor dan juga peranan penting yang diperankan oleh portofolio pasar, Arbitrage Pricing Theoryberoperasi dibawah asumsi yang relatif lebih sedikit. Karena penekanannya pada berbagai sumber dari resiko sistematis, Arbitrage Pricing Theory telah menarik banyak perhatian sebagai perangkat yang dalam dengan lebih baik menjelaskan hasil investasi dan mengontrol resiko portofolio dengan lebih efektif.

Dalam memprediksi akurasi model Arbitrage Pricing Theorydi lakukan dengan membandingkan expected return dan actual return dimana expected return adalah keuntungan yang diharapkan oleh investor dengan asumsi yang tidak pasti,pada awal periode factor risiko tidak dapat diprediksi oleh pasar karena factor risiko mengandung informasi yang tidak diharapkan atau bersifat mengejutkan pasar sedangkan actual return adalah keuntungan yang diharapkan. Dalam memprediksi akurasi model Arbitrage Pricing Theory dengan membandingkan expected return dan actual return maka jika expected return tidak sama dengan actual return maka tidak akurat sedangkan jika expected return sama dengan actual return maka akurat.Arbitrage Pricing Theorydidasari oleh pandangan bahwa expected return akan di pengaruhi oleh beberapa faktor risiko

\section{Tujuan Penelitian}

Tujuan penelitian ini adalah untuk mengetahui perbedaan expected return hasil prediksi model apt dengan actual return pada industri perbankan yang go public di bursa efek Indonesia.

\section{Teori Arbitrase Harga ( APT )}

\section{TINJAUAN PUSTAKA}

Capital Asset Pricing Model bukanlah satu-satunya teori yang mencoba menjelaskan bagaimana suatu aktiva ditentukan harganya oleh pasar. Ross (1976:259) merumuskan suatu teori yang disebut sebagai Arbitrage Pricing Theory (APT). Proses arbitrage terjadi karena adanya perbedaan harga sekuritas 
yang disebabkan oleh ketidak pastian harga (mispricing) sehingga investor dapat menjual asset yang mahal dan membeli asset yang murah. Suatu asset dinilai mispriced bila harganya berbeda dari harga yang diprediksikan menggunakan model valuasi di mana harga suatu asset adalah nilai sekarang dari cash flow di masa akan datang yang didiskontokan dengan biaya modal. Pendekatan Arbitrage Pricing Theorymenyatakan bahwa expected return suatu asset merupakan fungsi linear dari berbagai faktor ekonomi makro dan sensitifitas perubahan setiap faktor dinyatakan oleh koefisien beta masing-masing factor tersebut. Jadi Arbitrage Pricing Theory adalah sebuah pendekatan dalam menentukan harga suatu asset yang tidakbhanya didasarkan pada suatu vaiabel saja, tetapi banyak variabel maka dari itu

Tandelilin (2010) menyatakan salah satu model keseimbangan selain CAPM adalah Arbitrage Pricing Theory sama seperti CAPM, Arbitrage Pricing Theory menggambarkan hubungan antara risiko dan return tetapi dengan menggunakan asumsi dan prosedur yang berbeda. Arbitrage Pricing Theory didasari oleh pandangan bahwa return harapan untuk suatu sekuritas akan dipengaruhi oleh beberapa faktor risiko. Faktor-faktor risiko tersebut akan menunjukkan kondisi ekonomi secara umum dan bukan merupakan karekteristik seperti beikut ini:

1. Masing- masing faktor risiko harus mempunyai pengaruh luas terhadap return saham di pasar. Kejadian- kejadian khusus yang berkaitan dengan kondisi perusahaan bukan merupakan factor risiko Arbitrage Pricing Theory

2. Faktor-faktor tersebut harus mempengaruhi return harapan. Untuk itu perlu dilakukan pengujian secara empiris dengan cara menganalisis return saham secara statistik untuk melihat bagaimana faktor-faktor tersebut berpengaruh secara luas terhadap return saham

3. Pada awal periode, faktor risiko dapat diprediksi oleh pasar karena faktor-faktor risiko tersebut mengandung informasi yang tidak diharapkan atau sifat mengejutkan pasar

\section{Indeks Harga Saham Gabungan (IHSG)}

Indeks Harga saham gabungan (IHSG) atau dalam bahasa Inggrisnya disebut Jakarta Composite Index (JCI) atau JSX Composite diperkenalkan pada tanggal 1 April 1983, sebagai indikator pergerakan harga saham di BEJ, Indeks ini mencakup pergerakan harga seluruh saham biasa dan saham preferen yang tercatat di BEI. Fahmi dan Hadi (2008:72) faktor-faktor yang mempengaruhi suatu saham naik atau turun adalah:

1. Kondisi mikro dan makroekonomi.

2. Kebijakan perusahaan dalam memutuskan untuk ekspansi (perluasan usaha).

3. Pergantian direksi secara tiba-tiba.

4. Kinerja perusahaan yang terus mengalami penurunan dalam setiap waktunya.

5. Resiko sistematis, yaitu suatu bentuk resiko yang terjadi secara menyeluruh dan telah menyebabkan perusahaan terlibat didalamnya.

6. Efek dari psikologi pasar yang ternyata mampu menekan kondisi teknikal jual beli saham.

7. Kondisi eksternal, pengaruh dunia luar.

Dari uraian diatas bahwa IHSG dipengaruhi olah berbagai faktor yang sangat kompleks baik ekternal maupun internal yang mana IHSG merupakan indikator investor dalam menilai baik buruknya suatu pasar saham di suatu negara. Sensivitas dari IHSG karena adanya shock dari external factor maupun internal factor menunjukkan kondisi pasar saham yang masih sangat rentan dan belum mempunyai kepastian untuk meyakinkan investor.

\section{Nilai Tukar}

Shapiro (2005: 36) mendefinisikan "an exchange rate is simply, the price of one nation's currency in terms of another currency" atau nilai tukar adalah nilai suatu mata uang tertentu dinilai dengan mata uang negara lain misalkan Rupiah yang dinilai dari USD. Dimana nilai tukar ini dapat digolongkan menjadi spot rate dan forward rate. Spot rate adalah nilai tukar saat ini ketika sedang dilakukan transaksi, misalkan nilai mata uang rupiah (contohnya di bank komersial), sell Rp 9.020/USD sedangkan buy 9.000/USD. Sedangkan forward rate adalah nilai tukar mata uang dimasa yang akan datang yang telah ditentukan misalkan 2 bulan kedepan, yang dinilai saat ini. Dalam forward rate, dilakukan hedging terhadap nilai tukar dengan mempertimbangkan variabel fundamental ekonomi maupun situasi politik dan keamanan yang berpotensi untuk memberikan tekanan atau goncangan terhadap keseimbangan nilai tukar. 


\section{Inflasi}

Inflasi adalah suatu keadaan dimana nilai uang meneurun secara terbuka akibat harga barang yang cenderung naik. Ibbotson dan Brinson menyatakan "inflation is a sustained increase in the general price level over time". Pengaruh inflasi sangat besar bagi masyarakat di mana inflasi mengandung implikasi bahwa uang tidak dapat berfungsi sebagai satuan hitung yang adil dan benar. Inflasi dan devlasi adalah keadaan yang menggambarkan perubahantingkat harga dalam sebuah perekonomian. Dari beberapa definisi yang ada dapat disimpulkan bahwa inflasi merupakan suatu keadaan dimana menurunya nilai mata uang pada suatu Negara dan naiknya harga barang yang berlangsung secara sistematis. Dari definisi di atas dapat dipahami bahwa inflasi merupakan keadaan yang membayangkan bagi perekonomian suatu Negara dan mampu menimbulkan pengaruh yang besar serta sulit untuk diatasi dengan cepat Ketika konsep pertumbuhan ekonomi dirancang dan diaplikasikan maka ini selalu berhubungan dengan inflasi dikarenakan adanya trade-off inflasi di satu pihak dengan pertumbuhan ekonomi dan kesempatan kerja dipihak lain. Apabila inflasi diturunkan maka pertumbuhan ekonomi serta kesempatan kerja. Suatu efek target inflasi yang ditetapkan tidak tercapai adalah menurunnya minat berinvestasi dikalangan investor, efek lain bagi publik adalah menurunya daya beli dikarenakan pasar yang lesu. Bagi kalangan investor sangat penting untuk menurunkan inflasi di karenakan peningkatkan inflasi secara relatif merupakan signal negative bagi pemodal di pasar modal. Secara spesifik inflasi bias meningkatkan pendapatan dan biaya bagi perusahaan.

\section{Suku Bunga}

Suku bunga (interest rate) adlah kompensasi yang dibayar oleh peminjam yang meminjamkan.Bagi peminjam suku bunga merupakan biaya pinjaman atau harga yang harus di bayarkan atas uang yang dipinjamkan.Yang merupakan tingkat pertukaran dari konsumsi sekarang untuk konsumsi masa dating atau harga rupiah sekarang dalam ukuran rupiah masa datang. Konsep suku bunga sangat berhubungan dengan inflasi karena inflasi yang sangat tinggi tanpa di imbangi dengan kenaikan suku bunga maka akan bias terjadi keuntungan investasi terutama dipasar uang yang tidak menarik lagi sehingga dapat mengakibatkan melemahnya nilai tukar mata uang. Pihak yang berwenang menentukan suku bunga adalah Bank Sentral.

Gambar 1. Faktor-faktor yang mempengaruhi suku bunga

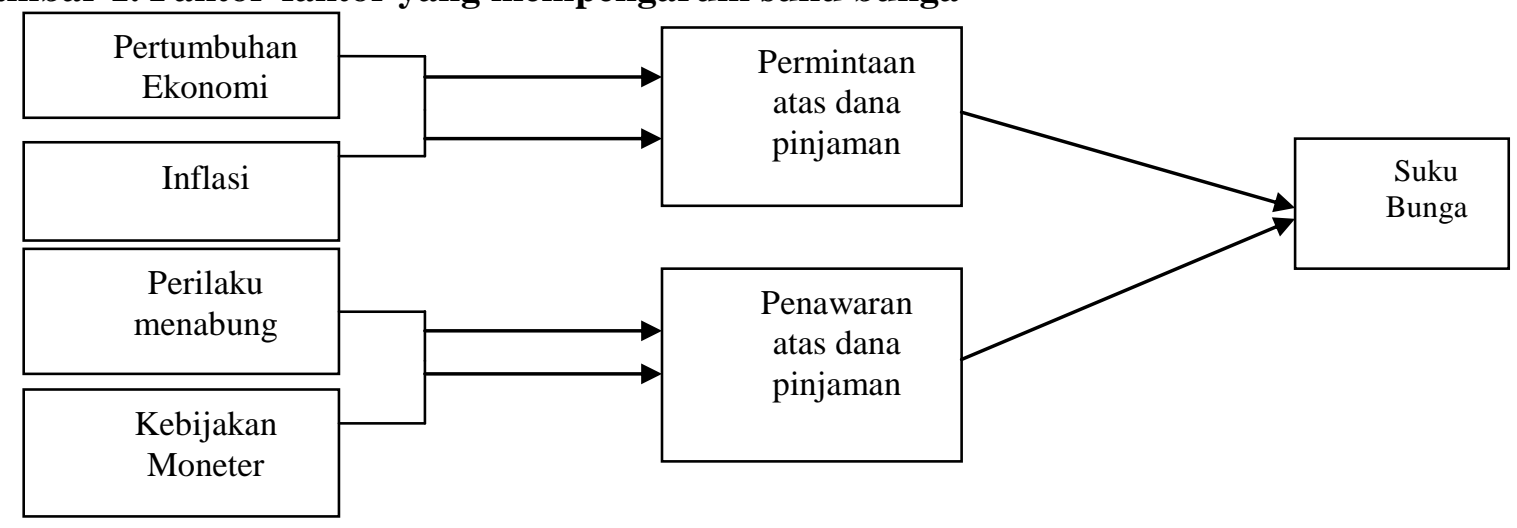

\section{Expected return}

Expected return adalah rata-rata dari suatu distribusi hasil yang mungkin. (Wikipedia Bahasa Indonesia, ensiklopedia bebas : 2008). Expected return adalah hasil yang diharapkan dari suau investasi. (Muslich,1997 :56). Expected return merupakan rata-rata tertimbang dari distribusi probabilitas. (Triatyati dan Husnan, $2004: 65)$.

$$
\begin{aligned}
& K=\sum K i . P i \\
& \quad \mathrm{i}=1 \\
& \mathrm{~K}=\text { tingkat keuntungan yang diharapkan ( Expected return }) \\
& \mathrm{Ki}=\text { tingkat keuntungan pada kondisi I } \\
& \mathrm{Pi}=\text { probabilitas kondisi } \mathrm{i} \text { terjadi } \\
& \mathrm{Pi}=\text { probabilitas kondisi i terjadi }
\end{aligned}
$$




\section{Actual return}

Keuntungan yang nyata dari suatu investasi bagi investor, hasil yang nyata bagi investor dari apa yang benar-benar mereka harapkan dari investasi mereka. (Wikipedia Bahasa Indonesia, ensiklopedia bebas ; 2008:161) Actual return adalah hasl yang nyata bagi investor dari suatu investasi, (Muslich, 1997 :

97). Untuk mencari actual return Actual $\operatorname{Re} t r u n=\frac{P t-P t-1}{P t-1}$

Dimana :

Harga saham hari ini ( $\mathrm{Pt}$ ) dikurangi harga saham kemarin ( Pt-1 ) dibagi dengan harga saham kemarin, ini berlaku untuk return pasar atau return actual. Ross et al. ( $2003: 238$ ), dan pernah digunakan oleh Suharli (2005:12)

\section{Minyak Bumi}

Minyak merupakan komodi tas utama didalam perekonomian modern. Seluruh aktivitas perekonomian serta industri tergantung dari stabilitas harga minyak. Hal ini dikarenakan peranan vital minyak sebagai sumber energi utama bagi sebagian besar proses produksi dan kegiatan perekonomian di seluruh belahan bumi. Fluktuasi harga minyak memiliki pengaruh besar terhadap seluruh rangkaian proses produksi maupun aktivitas modern, sehingga kenaikan atau penurunan kehidupan masyarakat dunia. Dalam era industri saat ini minyak bumi merupakan suatu hal yang sangat dibutuhkan oleh dalam menjalankan kegiatan sehari-hari.

\section{Hubungan Antara Konsep \\ Hubungan antara Arbitrage Pricing Theory dengan Harga Minyak Dunia}

Penelitian yang dilakukan oleh Jayadin (2012) meneliti bahwa hubungan antara prediksi return saham menggunakan model Arbitrage Pricing Theory dengan variabel karakteristik makroekonomi dalam penelitian ini adalah harga minyak mentah mengemukakan bahwa harga minyak mentah berpengaruh positifyang t-hitungnya $(0.0013,0.0000$ dan 0.0000$)$ lebih kecil dari t-tabel $(\alpha=0.05)$.

\section{Hubungan antara Arbitrage Pricing Theory dengan Inflasi}

Fitrah (2011) meneliti tentang Pengaruh Variabel Makroekonomi terhadap Imbal Hasil Saham dengan menggunakan pendekatan Arbitrage Pricing Theory. Ketidak pastian harga-harga saham yang diperdagangkan di bursa efek dari waktu ke waktu merupakan masalah yang ditemui di hampir semua bursa efek pada umumnya. Perubahan harga-harga saham dari periode ke periode menyebabkan imbal hasil saham menjadi tidak pasti. Salah satu model yang menggambarkan hubungan risiko dengan tingkat imbal hasil yang diharapkan adalah Arbirage Pricing Theory (APT). Penelitian ini membahas pengaruh variabel makro ekonomi laju inflasi, tingkat suku bunga, jumlah uang yang beredar, nilai tukar mata uang, dan aliran dana asing terhadap imbal hasil saham-saham JII yang konsisten selama periode Januari 2007-Mei 2010. Metode penelitian yang digunakan adalah analisis verifikatif dan deskriftif dengan teknik statistik dan ekonometrika. Penelitian menggunakan data time series dengan estimasi model menggunakan Regresi Linier Berganda. Hasil penelitian menunjukkan bahwa imbal hasil saham BUMI, INTP, KLBF dan TLKM signifikan dipengaruhi inflasi, tingkat suku bunga riil, kurs rupiah terhadap USD, jumlah uang beredar dan aliran dana asing. Kurs rupiah terhadap USD merupakan variabel yang dominan mempengaruhi imbal hasil masing-masing saham JII. Sementara itu dengan menggunakan data panel, aliran dana asing merupakan variabel yang paling dominan berpengaruh terhadap imbal hasil saham-saham JII, dimana terdapat hubungan negatif antara aliran dana asing dengan imbal hasil saham JII secara simultan.

\section{Hubungan antara Arbitrage Pricing Theory dengan IHSG}

Penelitian yang dilakukan Khasana (2007) tentang menganalisis return dan risiko saham LQ 45 variabel makroekonomi (kurs,SBI,IHSG,inflasi) dan menggunakan model alat uji Arbitrage Pricing Theory. Dari hasil uji regresi linier berganda penelitian di simpulkan bahwa return aktual saham akan naik jika suku bunga naik, inflasi turun, apresiasi rupiah dan menurunya IHSG dan dari uji t didapat risiko saham hanya dapat terjadi jika depresiasi terhadap rupiah dan peningkatan IHSG 


\section{Hubungan antara Arbitrage Pricing Theory dengan Nilai Tukar}

Penelitian yang dilakukan Sakhowi (1999) diperoleh kesimpulan dari hasil uji struktur regresi dari 2 kelompokobservasi yang dibedakan DER tinggi dan DER. rendah dengan menggunakan Chow test menghasilkan nilai $\mathrm{F}$ hitung sebesar 717.97 yang lebih besar dari $\mathrm{F}$ tabel $=2.51$ untuk taraf Selanjutnya hasil pengamatan terhadap return 7 portfolio yang diregresikan dengan variabel nilai tukar rupiah atas US dollar, suku bunga dan inflasi (variabel prediktor) menunjukkan terdapat perbedaan sensitivitas dan pengaruh yang signifikan antara industri yang berbeda terhadap perubahan tiga variabel prediktor. Secara keseluruhan hasil analisis dengan menggunakan model APT ini memiliki kemampuan untuk melakukan estimasi sehingga model yang dihasilkan layak untuk digunakan sebagai model dalam penilaian aset.

\section{Kerangka Pikir}

\section{KERANGKA PIKIR DAN HIPOTESA}

Berdasarkan kajian empiris dan kajian teoritis yang telah dipaparkan dalam bab sebelumnya dan melihat hasil penelitian terdahulu maka di simpulkan kerangka pemikiran teoritis penelitian di awali dari pemikiran bahwa keadaan pasar modal yang saat ini tidak memiliki kepastian akan expected return membuat para investor merasa takut dan ragu-ragu dalam berinvestasi. Hal ini di karenakan ketidak seimbangan antara return dan beta. Oleh karena itu Arbitrage Pricing Theory dapat dijadikan suatu predictor tingkat pengembalian saham pada industry perbankan yang terdaftar $\mathrm{d}$ bursa efek Indonesia

\section{Hipotesa Penelitian}

Berdasarkan kerangka pemikir yang telah diuraikan diatas maka hipotesa dari penelitian ini yaitu :

“ Diduga expected return hasil prediksi model Arbitrage Pricing Theory sama dengan actual return pada industry perbankan yang go public di Bursa Efek Indonesia"

\section{Data dan Sumber data}

\section{METODOLOGI PENELITIAN}

Jenis data dalam penelitian ini adalah data sekunder. Data sekunder adalah data yang diperoleh dari sumber-sumber lain, seperti buku dan bacaan lain, hasil analisa pasar yang berhubungan dengan masalah yang di teliti. Penelitian ini menggunakan data sekunder berupa laporan keuangan, harga saham, tingkat inflasi, IHSG, suku harga minyak mentah, dan nilai nilai tukar serta nilai return saham. Data yang digunakan adalah periode tahun 2009 - 2012

Sumber data dalam penelitian ini adalah bursa efek Indonesia data yang diperlukan untuk menguji hipotesis dalam penelitian ini adalah : harga saham perusahaan perbankan yang terdaftar di bursa efek indonesia tahun 2010-2011, IHSG, tingkat inflasi, suku harga minyak mentah, dan nilai kurs.

\section{Metode Pengumpulan Data}

Untuk mendapatkan informasi yang dilakukan proses pengumpulan data melalui dokumentasi. Untuk metode pengumpulan data yang dilakukan dengan membuat salinan dengan cara mengumpulkan arsip dan catatan-catatan perusahaan yang ada.Data yang dibutuhkan terdiri dari data sekunder yaitu data mengenai harga saham tingkat inflasi suku bunga dan nilai kurs diperoleh dari bursa efek Indonesia (BEI)

\section{Metode Pengambilan Sampel}

Populasi adalah seluruh elemen yang dapat digunakan untuk membuat beberapa kesimpulan (sekaran, 2003 :273) . Populasi dalam penelitian ini adalah perusahaan perbankan yang terdaftar di bursa efek Indonesia (BEI) sebanyak 25 Perusahaan perbankan. Teknik penarikan sampel dalam penelitian ini diambil dari 10 total perusahaan perbankan di bursa efek indonesia dari total populasi sebanyak 38 perusahaan dengan menggunakan metode purposive sampling, dimana sampel yang dipilih berdasarkan nilai asset dan harga saham perusahaan perbankan yang ada di bursa efek. Dari tingkat kepemilikan asset dan nilai saham diambil 10 perusahaan perbankan sebagai sampel yaitu :

1. PT. Bank Mandiri (Persero),Tbk

2. PT. Bank Rakyat Indonesia, Tbk

3. PT. Bank Central Asia, Tbk

4. PT. Bank Negara Indonesia (Persero), Tbk

5. PT. Bank CIMB Niaga, Tbk 
6. PT. Bank Danamon, Tbk

7. PT. Bank Permata, Tbk

8. PT. Bank Tabungan Pensiunan Negara, Tbk

9. PT. Bank OCBC NSIP, Tbk

10.PT. Bank Mega Tbk

\section{Metode Analisis}

\section{Uji-t berpasangan (paired t-test)}

Adalah salah satu metode pengujian hipotesis dimana data yang digunakan tidak bebas adalah dependen (berpasangan).Ciri-ciri yang paling sering ditemui pada kasus yang berpasangan yaitu suatu individu (objek penelitian) dikenal 2 buah perlakukan yang berbeda. Walaupun menggunakan individu yang sama, peneliti tetap memperoleh 2 macam data sampel, yaitu data dari perlakuan pertama dan data dari perlakuan kedua. Dengan demikian, suatu pengaruh dapat diketahui dengan cara membandingkan kondisi objek penelitian sebelum dan sesudah perlakukan

\section{Pengujian Hipotesis}

\section{Uji t-test}

Dalam melakukan pengujian hipotesis dengan t-test :

Bila sampel berkorelasi / berpasangan, misalnya membandingkan sebelum dan sesudah treatment atau perlakuan, maka di gunakan t-test sample related/ berpasangan

Rumus-rumus t-test :

$$
\begin{aligned}
& f=\frac{\bar{X}_{1}-\bar{X}_{2}}{\sqrt{\frac{S_{1}^{2}}{n_{1}}+\frac{S_{2}^{2}}{n_{2}}}} \\
& \text { (Separated Varians) } \\
& t=\frac{\bar{X}_{1}-\bar{X}_{2}}{\sqrt{\frac{\left(n_{2}-1\right) s_{1}^{2}+\left(n_{2}-1\right) s_{2}^{2}}{n_{1}+n_{2}-2}\left(\frac{1}{n_{1}}+\frac{1}{n_{2}}\right)}} \\
& t=\frac{\bar{X}_{1}-\bar{X}_{2}}{\sqrt{\frac{s_{1}^{2}}{n_{1}}+\frac{s_{2}^{2}}{n_{2}} 2 r\left(\frac{s_{1}}{\sqrt{n_{1}}}\right)\left(\frac{s_{1}}{\sqrt{n_{2}}}\right)}} \text { Untuk sampel berpasangan / related }
\end{aligned}
$$

Adapun langkah-langkah pengujiannya adalah sebagai berikut :

a. Membuat formulasi uji hipotesis

Tentukan hipotesis nol dan hipotesis alternative

H0 $\quad: \quad \mu \mathrm{d} \quad=0 \quad$ Tidak terdapat perbedaan Actual return dan Expected return

1. PT.Bank Mandiri (Persero),Tbk

2. PT.Bank Danamon, Tbk

3. PT.Bank Rakyat Indonesia, Tbk

4. PT.Bank Negara Indonesia, Tbk

5. PT.Bank Capital Indonesia, TBk

6. PT.Bank Central Asia, Tbk

7. PT.Bank CIMB Niaga, Tbk

8. PT.Permata, Tbk

9. PT.Bank Tabungan Negara, Tbk

10.PT.Bank OCBC NISP, Tbk,Tbk

$\mathrm{H} 0 \quad: \quad \mu \mathrm{d} \quad \neq 0 \quad$ terdapat perbedaan Actual return dan Expected return

1. PT.Bank Mandiri (Persero),Tbk 
2. PT.Bank Danamon, Tbk

3. PT.Bank Rakyat Indonesia, Tbk

4. PT.Bank Negara Indonesia, Tbk

5. PT.Bank Capital Indonesia, TBk

6. PT.Bank Central Asia, Tbk

7. PT.Bank CIMB Niaga, Tbk

8. PT.Permata, Tbk

9. PT.Bank Tabungan Negara, Tbk

10.PT.Bank OCBC NISP, Tbk,Tbk

b. Menentukan besarnya $\alpha$ untuk mengetahui tingkat signifikan hasil pengolahan data. Nilai $\alpha$ ditetapkan sebesar $5 \%$ atau signifikan $95 \%$

c. Menghitung nilai $t$

d. Membuat kriteria pengujian hipotesis

Ho Ditolak bila :

Sig. $\mathrm{t}<\alpha(\alpha=0,05)$

Ho gagal ditolak bila :

Sig. $\mathrm{t}>\alpha(\alpha=0,05)$

\section{HASIL ANALISIS DAN PEMBAHASAN}

Berdasarkan hasil regresi maka persamaan model Arbitrage Pricing Theory setiap perusahaan di peroleh sebagai berikut:

1. Bank Central Asia adalah ERI $=0.181+0.000 \times 1-0.130 \times 2-0.000001 \times 3-0.00001 \times 4$

2. Bank CIMB adalah ERI $=0.037+0.0001 \mathrm{X} 1+0.143 \mathrm{X} 2-0.00001 \mathrm{X} 3-0.00001 \mathrm{X} 4$

3. Bank Danamon adalah ERI $=0.095+0.000 \times 1-0.400 \times 2-0.0000002 \times 30.0000070 \times 4$

4. Bank Mandiri adalah ERI $=0.367+0.000$ X1 -0.269 X2 -0.0000016 X3-0.0000357 X4

5. Bank Mega adalah ERI $=-0.037+0.000 \mathrm{X} 1+0.393 \mathrm{X} 2-0.0000068 \mathrm{X} 3-0.0000066 \mathrm{X} 4$

6. Bank Negara Indonesia adalah ERI $=0.49+0.0000590 \mathrm{X} 1+0.073 \mathrm{X} 2-0.0000169 \mathrm{X} 3-0.0000487 \mathrm{X} 4$

7. Bank OCBC NISP adalah ERI $=0.324-0.002 \mathrm{X} 1-0.213 \mathrm{X} 2+0.0000213 \mathrm{X} 3-0.0000257 \mathrm{X} 4$

8. Bank Permata Indonesia adalah ERI $=0.362+0.000 \mathrm{X} 1-0.456 \mathrm{X} 2+0.0000016 \mathrm{X} 3-0.0000363 \mathrm{X} 4$

9. Bank Rakyat Indonesia adalah ERI $=0.261+0.000$ X1 -0.097 X2 $-0.0000040 \mathrm{X} 3-0.0000253 \mathrm{X} 4$

10.Bank Tabungan Pensiunan Nasional adalah

$\mathrm{ERI}=-0.181-0.001 \mathrm{X} 1-0.125 \mathrm{X} 2+0.0000074 \mathrm{X} 3+0.0000236 \mathrm{X} 4$

\section{Pengujian Hipotesa}

\section{Tabel 2. Hasil Uji SPSS}

Paired Samples Test

\begin{tabular}{|c|c|c|c|c|c|c|c|c|c|}
\hline & & \multicolumn{5}{|c|}{ Paired Differences } & \multirow[b]{3}{*}{$t$} & \multirow[b]{3}{*}{ df } & \multirow[b]{3}{*}{ Sig. (2-tailed) } \\
\hline & & \multirow[b]{2}{*}{ Mean } & \multirow[b]{2}{*}{ Std. Deviation } & \multirow{2}{*}{$\begin{array}{c}\text { Std. Error } \\
\text { Mean }\end{array}$} & \multicolumn{2}{|c|}{$\begin{array}{l}95 \% \text { Confidence } \\
\text { Interval of the } \\
\text { Difference }\end{array}$} & & & \\
\hline & & & & & Low er & Upper & & & \\
\hline $\begin{array}{l}\text { Pail } \\
1\end{array}$ & $\begin{array}{l}\text { ERi_Gabung } \\
\text { - Ri_Gabung }\end{array}$ & -.0490655 & .5061271 & .0462029 & -.1405518 & .0424208 & -1.062 & 119 & .290 \\
\hline
\end{tabular}

Setelah melakukan uji hipotesa menggunakan SPSS maka di peroleh output berupa hasil pengujian beda dua rata-rata dependent samples, seperti terlihat pada tabel 2 bahwa $t_{\text {hitung }}$ untuk pengujian APT dengan membandingkan actual return (Ri) dan expected return (ERi) saham dengan equal variance asumet adalah $0,1.620$ dengan propabilitas 0,290 . oleh karena nilai $-\mathrm{P} 0,290>0,05$, Hasil penelitian menunjukan bahwa expected return tidak berbeda signifikan dengan actual return (signifikan 0.290) ini berarti hipotesis menyatakan : Diduga expected return hasil prediksi model i sama dengan actual return pada industri perbankan yang go public di Bursa Efek Indonesia ditolak. Oleh karena expected return tidak berbeda signifikan dengan actual return maka model Arbitrage Pricing Theory Akurat.

\section{Pengujian Tambahan (antar perusahaan)}

Pengujian tambahan dilakukan juga pada setiap perusahan dengan menggunakan SPSS diperoleh output berupa hasil pengujian beda dua rata-rata dependent samples, seperti terlihat pada tabel 3 Dengan hasil sebagai berikut: 
Tabel 3 Hasil Uji Paired Samples Test

\begin{tabular}{|c|c|c|c|c|c|c|c|c|c|}
\hline \multicolumn{10}{|c|}{ Paired Samples Test } \\
\hline & & \multicolumn{5}{|c|}{ Paired Differences } & \multirow[b]{3}{*}{$t$} & \multirow[b]{3}{*}{ df } & \multirow[b]{3}{*}{ Sig. (2-tailed) } \\
\hline & & \multirow[b]{2}{*}{ Mean } & \multirow[b]{2}{*}{ Std. Deviation } & \multirow{2}{*}{$\begin{array}{l}\text { Std. Error } \\
\text { Mean }\end{array}$} & \multicolumn{2}{|c|}{$\begin{array}{l}95 \% \text { Confidence } \\
\text { Interval of the } \\
\text { Difference }\end{array}$} & & & \\
\hline & & & & & Low er & Upper & & & \\
\hline Pair 1 & ERi_BCA - RI_BCA & .02065 & .07121 & .02056 & -.02460 & .06590 & 1.004 & 11 & .337 \\
\hline Pair 2 & ERI_niaga - RI_Niaga & .07957 & .10307 & .02975 & .01409 & .14506 & 2.674 & 11 & .022 \\
\hline Pair 3 & $\begin{array}{l}\text { ERI_Danamon - RI_ } \\
\text { Danamon }\end{array}$ & .03361 & .07489 & .02162 & -.01398 & .08119 & 1.555 & 11 & .148 \\
\hline Pair 4 & ERi_Mandiri - RI_Mandiri & .02472 & .09381 & .02708 & -.03489 & .08432 & .913 & 11 & .381 \\
\hline Pair 5 & ERI_Mega - RI_mega & -.12401 & .10914 & .03151 & -.19336 & -.05467 & -3.936 & 11 & .002 \\
\hline Pair 6 & ERI_BNI - RI_BNI & .00636 & .09353 & .02700 & -.05306 & .06579 & .236 & 11 & .818 \\
\hline Pair 7 & ERI_NISP - RI_NISP & .00610 & .09256 & .02672 & -.05271 & .06492 & .228 & 11 & .824 \\
\hline Pair 8 & $\begin{array}{l}\text { ERI_PErmata - RI } \\
\text { PErmata }\end{array}$ & -.19557 & 1.10209 & .31815 & -.89580 & .50466 & -.615 & 11 & .551 \\
\hline Pair 9 & ERI_BRI - RI_BRI & -.00650 & .09841 & .02841 & -.06902 & .05603 & -.229 & 11 & .823 \\
\hline Pair 10 & ERI_BTPN - RI_BTPN & -.33558 & 1.15027 & .33206 & -1.06643 & .39527 & -1.011 & 11 & .334 \\
\hline
\end{tabular}

Untuk Bank BCA : Hasil Penelitian menunjukan bahwa Expected return Tidak Berbeda signifikan dengan actual return (signifikan 0.337) ini berarti expected return hasil model Arbitrage Pricing Theory sama dengan actual return

Untuk Bank Niaga : Hasil Penelitian menunjukan bahwa Expected return Berbeda signifikan dengan actual return (signifikan 0.022) ini berarti expected return hasil model Arbitrage Pricing Theory tidak sama dengan actual return

Untuk Bank Danamon : Hasil Penelitian menunjukan bahwa Expected return Tidak Berbeda signifikan dengan actual return (signifikan 0.148) ini berarti expected return hasil model Arbitrage Pricing Theory sama dengan actual return

Untuk Bank Mandiri : Hasil Penelitian menunjukan bahwa Expected return Tidak Berbeda signifikan dengan actual return (signifikan 0.381) ini berarti expected return hasil model Arbitrage Pricing Theory sama dengan actual return

Untuk Bank Mega : Hasil Penelitian menunjukan bahwa Expected return Berbeda signifikan dengan actual return (signifikan 0.002) ini berarti expected return hasil model Arbitrage Pricing Theory tidak sama dengan actual return

Untuk Bank BNI : Hasil Penelitian menunjukan bahwa Expected return Tidak Berbeda signifikan dengan actual return (signifikan 0.818) ini berarti expected return hasil model Arbitrage Pricing Theory sama dengan actual return

Untuk Bank NISP : Hasil Penelitian menunjukan bahwa Expected return Tidak Berbeda signifikan dengan actual return (signifikan 0.824) ini berarti expected return hasil model Arbitrage Pricing Theory sama dengan actual return

Untuk Bank PERMATA : Hasil Penelitian menunjukan bahwa Expected return Tidak Berbeda signifikan dengan actual return (signifikan 0.824) ini berarti expected return hasil model Arbitrage Pricing Theory sama dengan actual return

Untuk Bank BRI : Hasil Penelitian menunjukan bahwa Expected return Tidak Berbeda signifikan dengan actual return (signifikan 0.823) ini berarti expected return hasil model Arbitrage Pricing Theory sama dengan actual return

Untuk Bank BNI : Hasil Penelitian menunjukan bahwa Expected return Tidak Berbeda signifikan dengan actual return (signifikan 0.334) ini berarti expected return hasil model Arbitrage Pricing Theory sama dengan actual retur

\section{Pembahasan}

Hasil penelitian yang dilakukan oleh penulis, menyatakan bahwa pengujian APT (Arbitrase Pricing Theory) dengan membandingkan Actual return (Ri) dengan Expected return (ERi) untuk mengukur tingkat pengembalian saham adalah tidak terdapat perbedaan. Ini berarti bahwa APT tidak memberikan dampak tingkat pengembalian saham pada perusahaan-perusahaan perbankan yang go public di bursa efek Indonesia.Hasil dan pengujian hipotesis mengenai perbandingan Actual return (Ri) dengan Expected return (ERi) tidak ada perbedaan antara kedua periode ini perhitungan perbandingan Actual return (Ri) dengan Expected return (ERi) 
atas kedua periode ini menunjukkan tidak ada perbedaan yang tidak signifikan berdasarkan uji beda dua ratarata.

Kuhn (a new approach to testing aset pricing models 'jurnal of finance 38, 1983:711-743") mengemukakan bahwa paradikma yang baru dari yang lama menunjukan jumlah bentuk dari fenomena pengamatan yang ganjil kemudian. Dengan alasan ini, kebanyakan tes yang berhasil dilakukan oleh APT menjadi perhatian dengan kemampuan yang dilakukan oleh APT sebagai penunjuk prediksi dari sejumlah hasil yang tidak dapat diprediksi oleh CAPM: dampak dari firma kecil, efek januari, dan yang lainya. Bagian dari DHRYMES kebanyakan menjaga bagian dari seksi II, yang termasuk uji contoh dari resiko prediksi komponen dan resiko pengukuran tak terprediksi dalam penjelasan subsekuen.Menurut saya hasil dari uji ini merupakan bukti yang sangat penting yang harus dikonfrontasi dalam segala asset yang mendukung bagi APT ataupun CAPM.

Dengan pertimbangan spesifik dari uji seksi II ini, I harus menyebutkan dua poin yang penting untuk dipertimbangkan.Perhatian pertama haruslah merupakan pemikiran yang tidak terikat.Dampak dari penyebaran ini memperkenalkan korelasi yang negative berdasarkan penutupan penetapan harga yang harus sesuai dengan estimasi variansi dari uji statikkal.Poin 2 merupakan contoh tes mekanisme alternative yang mampu memisakan menjadi dua contoh.Sebuah contoh yang diatur dalam pengamatan, mengunakan semua data untuk menjelaskan pengamatan, penanggulangan dari setiap prosedur pengamatan yang berhasil dan analisa hasil diri prediksi dan kesalahan". Pengamatan terakhir saya dalam debat mengenai uji APT melalui faktor analisa yang adalah lembaran awal yang terlihat dari pengamatan dalam isu yang terdapat dalam sesi ini yang membuat beberapa posisi terdektesi dalam tahap ini. Situasi ini menempatkan saya dalam posisi yang sama sedikitnya satu potensial, faktor resiko sistimatik yang tidak dapat dianalisa. Sejak faktor analisa ini diperhatikan dari faktor matriks kovariansi dri produk" tersebut yang tidak dapat diambil dalam sistimatik tersebut.

\section{Kesimpulan}

\section{KESIMPULAN DAN SARAN}

Penelitian ini meneliti pengujian APT dengan membandingkan Actual return (Ri) dan Expected return (ERi) terhadap tingkat pengembalian saham pada

1. PT. Bank Mandiri (Persero), Tbk

2. PT. Bank Rakyat Indonesia, Tbk

3. PT. Bank Central Asia, Tbk

4. PT. Bank Negara Indonesia (Persero), Tbk

5. PT. Bank CIMB Niaga, Tbk

6. PT. Bank Danamon, Tbk

7. PT. Bank Permata, Tbk

8. PT. Bank Tabungan Pensiunan Negara, Tbk

9. PT. Bank OCBC NSIP, Tbk

\section{PT. Bank Mega Tbk}

Berdasarkan analisis hasil penelitian, maka dapat ditarik kesimpulan sebagai berikut : dari hasil uji beda dua rata-rata ditemukan bahwa selama periode penelitian yaitu Januari - Desember 2011 perbedaan actual return (Ri) dan Expected return (ERi) tidak signifikan

\section{Saran}

Saran yang dapat diberikan berkaitan dengan hasil analisis dan pembahasan pada penelitian ini adalah :

1. Penilaian prestasi suatu perbankan dapat dilihat dari kemampuan perbankan itu menghasilkan laba. Dengan kata lain, perusahaan harus meningkatkan kinerja perusahaan agar dapat memenuhi kewajiban bagi para penyandang dana (investor) dan perusahaan itu sendiri dalam hal pengembalian return saham

2. Penelitian ini menggunakan perbandingan antara actual return (Ri) dan Expected return (ERi) terhadap tingkat pengembalian return saham. Disarankan bagi penelitian selanjutnya untuk mengganti atau melengkapi variabel yang diuji

3. Hendaknya dilakukan penelitian lanjutan yang sejenis dengan penelitian ini dengan cara memperluas sampel penelitian dan data penelitian

\section{DAFTAR PUSTAKA}

Agus, Sartono. 2001. Manajemen Keuangan Teori dan Aplikasi. Edisi Keempat. Cetakan Pertama. BPEE. Yogyakarta. 
Kewon, Arthur J., Scott, David F., Martin, Jr. John D., Petty, J. William. 2001. Dasar-dasar Manajemen Keuangan. Buku 1.Salemba Empat. Jakarta.

Damodaran, Aswath. 2002. Investment Valuation (second Edition). John Wiley \& Sons, Inc. New York.

Fama, Eugene F., French, Kenneth R. "The Cross-section of Expected stockReturns". Journal of finance, Vol. 47, No.2, $1992: 427-465$.

Hasan, Iqbal. 2008. Analisis Data Penelitian Dengan Statistik. Edisi ketiga. Bumi Aksara. Jakarta.

Husnan, Suad., Pudjiastuti, Enny. 2002. Dasar-dasar Manajemen Keuangan. Edisi Ketiga. YKPN. Yogyakarta. Indriantoro., Supomo. 2002. Metodologi Penelitian Bisnis. BPFE UGM. Yogyakarta.

Mahmud, M., Abdul Halim. 1996. Analisis Laporan Keuangan. UPP AMP YKPN. Yogyakarta.

Hanafi, Martono., Harjito, D.A. 2004. Manajemen Keuangan. Cetakan Keempat. Eknosia. Yogyakarta.

Sugiyono. 2005. Metode Penelitian Bisnis. Cetakan Kedelapan. CV Alfabet. Bandung.

Weston, J. Fred., Brigham, Eugene F. 1990. Dasar-dasar ManajemenKeuangan. Jilid 2. Edisi Kesembilan. Terjemahan oleh Alfonsus Sirait. Erlangga. Jakarta.

Website : $\quad$ - Bursa Efek Indonesia. www.idx.co.id

- www.google.com

Aliansyah, M. Noor. 2001. Pengaruh Struktur Modal TerhadapNilaiSaham. Manajemen Usahawan Indonesia. Jakarta.

Halim, Abdullah. 2005. Analisis Investasi. Salemba Empat. Jakarta.

Haryanto., Sugiharto. 2003.Pengaruh Rasio Profitabilitas Terhadap Harga Saham Pada Perusahaan Minuman Di Bursa Efek Jakarta. Fakultas Ekonomi. Universitas Gunadarma.

Husnan, Suad. 2004. Manajemen Keuangan Teori dan Penarapan (Keputusan Jangka pendek). Buku 1. Edisi 4. BPFE. Yogyakarta.

Lutfia, Lutfanida. 2006. Pengaruh Return On Investment, Operating CashFlow dan Economic Value Added Terhadap Tingkat PengembalianSaham.

Suara Merdeka (Kamis,21 oktober 2004)

Chairul, Anwar. Studi peristiwa Reaksi Pasar terhadap Pemilihan Umum 5 April 2004 pada Bursa Efek Jakarta.

Soetrisno. 2003. Dasar-dasarManajemen Keuangan. Ekonosia Fakultas Ekonomi UII. Yogyakarta.

Tandelilin, Eduardus. 2001. Analisis Investasi dan Manajemen Portofoli. Edisi pertama. BPFE UGM. Yogyakarta.

Trisnawati. 2002. Dept of Economic and Development Studies. Salemba Empat. Jakarta.

Bank Indonesia. 1997-2010. Statistik Ekonomi dan Keuangan Indonesia (SEKI). Bank Indonesia. Jakarta.

Bapepam. 2008. Analsis Kointegrasi dan Kausalitas serta Hubungan Dinamis Antara Aliran Modal Asing, Perubahan Nilai Tukar Dan Pergerakan IHSG Di Pasar Modal Indonesia. Bapepam Dan Departemen Keuangan.

Choudhry, Moorad., Joannas, Didier., Pereira, Richard., Pienaar, Rod. 2002. Capital Market Instrument: Analysis and Valuation. Financial Series. Prentice Hall. Great Britain

Chieh, Ming. W., Ming, F. S. 2010. Volatility Spillover Dynamic Regional And World Effect. European Journal of Finance and Banking Research Vol. 3. No. 3.

Dwipraptono, Agus Harjito.2010. Perubahan Musiman (Seasonality) Pasar Modal Dan Efek Kontagion Di Negara-Negara Asean. Universitas Islam Indonesia. Yogyakarta.

Fabiola, Ravazzolo. 2000. Stock Price and Exchange Rate Dynamics. www.google.com

Fahmi, Irham., Hadi, Y. Lavianti. 2008. Teori Portofolio Dan Analisis Investasi. Alfabeta. Bandung

Gan, C at al .2006. Macroeconomic Variables And Stock Market Interactions: Newzealand Evidence. Investment Management and Financial Innovations, Volume 3, Issue 4

Gujarati, Damodar. 1995. Econometrics, $2^{\text {nd }}$. McGraw Hill International, Inc. USA.

Husnan, Suad, 1998. Pengujian CAPM di BEJ Periode 1994-1997 : Standard CAPM ataukah Zero Beta ?. JurnalEkonomidanBisnis Indonesia, Vol. 13, No. 4, hal: 89-97. 